\title{
Emotional Intelligence and Burnout in Managers
}

\author{
Dr. Sobia Aftab \\ Associate Professor and Clinical Psychologist \\ Institute of Clinical Psychology, University of Karachi \\ Karachi, Pakistan \\ drsobia_psy@yahoo.com
}

\author{
Kanwal Qadeer \\ PhD. Intern in Clinical Psychology \\ Institute of Clinical Psychology, University of Karachi \\ Karachi, Pakistan \\ qadeer.kanwal@gmail.com
}

\begin{abstract}
The objective of the present study was to investigate the predictive association between emotional intelligence and burnout in people working at managerial level. A purposive sample of 100 managers was recruited from different organizations in Karachi, Pakistan. Their ages ranged from 23 to 62 years with the mean age of $\mathbf{3 5 . 6 4}$ years. The measures used along with Demographic Form in the study included: (1) The Assessing Emotions Scale (Schutte, Malouff \& Bhullar, 2009); (2) Burnout Questionnaire (American Public Welfare Association, 1981). Linear Regression Analysis was computed to interpret the data in statistical terminology. The analyses reveal significant predictive relationship of Perception of Emotion, Managing Own Emotions and Total Emotional Intelligence (T-EI) with burnout. However, Managing Other's Emotions and Utilization of Emotions are found as insignificant predictors of Burn Out. These findings have implications for management level in organizations and also open avenues for future research.
\end{abstract}

Keywords: emotional intelligence; burnout; managers; organization; psychological syndrome

\section{INTRODUCTION}

Numerous researches have been conducted on the role of emotional intelligence in people working at managerial level in various organizations. It has been proposed by researchers that there is a probability that emotionally intelligent managers may be more successful than their counterparts (Caruso \& Salovey, 2004; George, 2000). Another theory proposes that it may be due to the fact that managers are given emotional intelligence services by consultancies to select and train them (Schmit, 2006). There are researches that provide evidence in supporting this enthusiasm (Jordan, Ashton-James, \& Ashkanasy, 2006), but there is also considerable debate about the qualities of emotional intelligence. This debate arises, partially, because there is lack of theories and tests of how emotional intelligence is related to managerial outcomes including stress and burnout (Murphy, 2006). Hence, the purpose of this study is to explore whether emotional intelligence is associated with burnout in managers.

According to the Salovey and Mayer's (1990) original model, emotional intelligence consists of appraisal of emotion in the self and others, emotional expression, regulation of emotion in the self and others, and utilization of emotion in solving problems. Mayer, Salovey, and Caruso (2004) later on refined their 1990 model but the basic aspect of emotional intelligence proposed remained similar to the old model. In their 1990 model, Salovey and Mayer described emotional intelligence as a mix of what might be considered abilities and traits whereas, in the recent model, they have argued for a pure ability conceptualization of emotional intelligence. Such an ability conceptualization is associated with a measurement approach that focuses on latent abilities assessed through performance tasks (Mayer et al., 2004; Mayer, Salovey, Caruso, \& Sitarenios, 2003).

Emotional Intelligence, along with the ability of carefully reason emotional feelings (Mayer et al., 2008) also includes other characteristics like the ability to excite oneself, ability to resist failures, maintaining one's morals, repressing depression during thinking, empathy, intimacy and optimism (Goleman, 1995). This not only helps in controlling emotional responses, but it also facilitates the appropriate exploitation of emotions in various situations and can predict reductions in burnout (Mayer et al., 2008). Emotional intelligence by adequately processing the events which bear emotional load, empower the individual to sensibly deal with the events, apply continence and control immediate demands. It, therefore, may be argued that, considering its significant role in emotional control including appropriate emotional management and individual's adaptability to the environment, Emotional intelligence may help in reducing burnout and enhance emotional control (Goleman, 1998).

Burnout is a psychological syndrome that involves a prolonged response to work stressors (Maslach, Schaufeli, \& Leiter, 2001). The issue of burnout was defined for the first time by Freudenberger (1974) which gave rise go further studies. According to Carman (2001) burnout is a public phenomenon that arises from mutual actions and individual's personality adjustment to job environment. Burnout is not only a result of tiredness and job pressure that occurs due to continuous working, but it also transmits to individual's general life style in their waking hours. Maslach and Jackson (1993) defined exhaustion and long term physical pressure including job Bureaucracy and excessive workload as two factors physical or mental burnout. Understanding the associations of the burnout of managers is important because burnout has several negative consequences, including poor performance, turnover, alcohol and drug abuse, somatic symptoms, and abusive behavior (Cordes \& Dougherty, 1993; Lee \& Ashforth, 1996; Maslach, Jackson, \& Leiter, 1996). Facing considerable demands and frequently encountering challenging social interactions maybe leading to relatively high risk for burnout (Cordes \& Dougherty, 1993). In addition, managers' burnout may have wide ranging consequences in organizations because managers may contaminate their 
subordinates through a contagion process (Lee \& Ashforth, 1993).

In the past, a few studies have examined emotional intelligence and burnout in undergraduate students and employees with no managerial responsibilities (Day, Therrien, \& Carroll, 2005), but no study has specifically examined managers. Slaski and Cartwright (2003) argued that emotional intelligence could serve as a moderator in the stress process that precedes burnout. Furthermore, individuals with high emotional intelligence will perceive work experiences to be less stressful and thus experiences less health consequences. Hence it is a useful model to describe how emotional intelligence is associated with managerial burnout. Consistent with previous arguments for treating emotional intelligence as a latent multidimensional construct (Côté \& Miners, 2006; Wong \& Law, 2002), we focus our analyses on the broad construct of emotional intelligence along with its dimensions and their relationship with burnout in managers. The findings obtained in the present study will not only be a valuable addition to the existing literature but will also help in developing an understanding of the relative contribution of each aspect of emotional intelligence in burnout at managerial level. The knowledge gain will also help concerned counselor to formulate therapeutic strategies accordingly while keeping in consideration the evident trends.

\section{METHODOLOGY}

\section{A. Sample}

A purposive sample of 100 individuals (63 males and 37 females) working as managers at various organizations (including Banks, NGO’s, Media, Schools and Multi-National Companies) of Karachi-Pakistan were recruited. Their ages ranged from 23- 62 years with mean age of 35.64 years. It was made sure that all the people selected as a sample worked on a managerial level in their organization.

\section{B. Measures}

\section{Demographic Form:}

The demographic form was self-developed based on the established research criteria. It focused on participant's demographic details and specific questions related to their occupational history.

The Assessing Emotions Scale:

The Assessing Emotions Scale is a 33-item self-report inventory focusing on typical emotional intelligence. Respondents rate themselves on the items using a five-point scale. Respondents require on average five minutes completing the scale. The most widely used subscales derived from the 33-item Assessing Emotions Scale are those based on factors identified by Petrides and Furnham (2000), Ciarrochi et al. (2001), and Saklofske et al. (2003). The four factors were described as follows: perception of emotions, managing emotions in the self, social skills or managing others' emotions, and utilizing emotions. In the development sample of 346 participants, Schutte et als found the internal consistency of the Assessing Emotions Scale, as measured by Cronbach's alpha, to be .90 .
Burnout Questionnaire:

The Burnout Questionnaire developed by the American Public Welfare Association in 1981 was used in the present study to assess burnout in managers. It comprised of 25 items rated on a 5-point Likert Scale ranging from $1=$ never to $5=$ =always. Cronbach's alpha obtained in the present study is .835 which indicates good internal consistency of the scale.

\section{Procedure}

The managers selected as a sample were first contacted through email where they were informed about the purpose of the research and their consent was taken. If the contacted managers voluntarily agreed to take part in the research then a time of meeting based on their convenience was fixed with them. A lot of difficulty was faced in deciding appointments as the managers are usually caught up in their busy routines which resulted in many cancellations and rescheduling. Upon meeting, the managers were ensured that the questionnaire would not take more than 15 minutes. First the consent form was handed over to them for review and signature followed by the demographic form. Afterwards, Assessing Emotions scale (Schutte, Malouff \& Bhullar, 2009) and then Burnout Questionnaire (American Public Welfare Association, 1981) were administered. Upon completion, the managers were thanked for their valuable time and cooperation.

\section{Scoring and Statistical Analysis}

After data collection, the research measures were scored according to the standard scoring procedures. To test the hypotheses of the present study, Linear Regression Analysis was computed. Descriptive statistics was also utilized.

\section{RESUlTS}

TABLE I.

\begin{tabular}{|l|c|c|}
\hline \multirow{2}{*}{} & \multicolumn{2}{|c|}{ Descriptive Statistics for Age of Entire Sample } \\
\cline { 2 - 3 } & $\boldsymbol{M}$ & $\boldsymbol{S D}$ \\
\hline Age & 35.65 & 8.966 \\
\hline
\end{tabular}

TABLE II.

\begin{tabular}{|c|c|c|c|c|c|}
\hline $\begin{array}{c}\text { Depen } \\
\text { dent } \\
\text { Variab } \\
\text { les }\end{array}$ & \multicolumn{5}{|c|}{$\begin{array}{c}\text { Summary of Linear Regression with Perception of } \\
\text { Emotion (PE), Managing Own Emotions (MOE), } \\
\text { Managing Other's Emotions (MOTE), Utilization of } \\
\text { Emotions (UE), and Total Emotional Intelligence (T- } \\
\text { EI) as predictor of Burn Out }\end{array}$} \\
\hline PE & $\boldsymbol{R}$ & $\boldsymbol{R}^{2}$ & Adj $\boldsymbol{R}^{2}$ & $\boldsymbol{F}$ & Sig. \\
\hline MOE & .250 & .062 & .053 & 6.514 & .012 \\
\hline MOTE & .252 & .064 & .054 & 6.645 & .011 \\
\hline UE & .151 & .023 & .013 & 2.298 & .113 \\
\hline T-EI & .061 & .004 & -.006 & .365 & .547 \\
& & & & & \\
\hline
\end{tabular}


TABLE III.

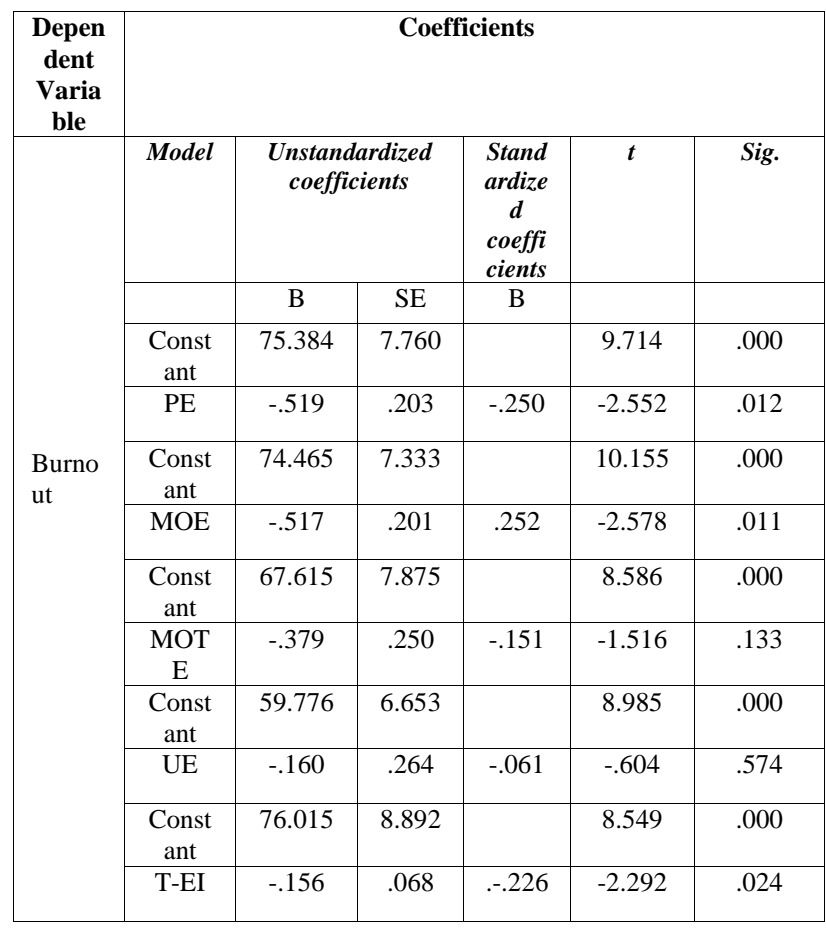

\section{DISCUSSION}

Statistical analysis of the data showed significant predictive association between Emotional Intelligence and Burnout in Managers. Moreover, key findings regarding different domains of emotional intelligences are as follow: Perception of Emotion and Managing Own Emotions are found as significant predictors of burnout. However, Managing Other's Emotions and Utilization of Emotions are found as insignificant predictors of Burnout. These findings suggest that managers may avoid burnout by being emotionally intelligent or in order to avoid burnout, those managers should be hired who are emotionally intelligent.

These findings show that our results are theoretically useful because they inform researchers as to how emotional intelligence may be associated with managerial outcomes such as burnout. Our findings also inform the scientific status of the concept of emotional intelligence. At the outset, we noted that a lack of theory and empirical research is largely responsible for intense and persistent debates about the utility of emotional intelligence for organizational research and managerial practice (Murphy, 2006). Our results inform those debates by showing how emotional intelligence is associated with important management outcomes that have not been examined in past research.

This research can also be helpful in designing interventions to reduce burnout among managers. Previous researches show that interventions to reduce burnout are difficult to design and evaluate because researchers rarely have control over the environmental aspects of work that are proposed to relate to burnout (Maslach et al., 1996). However, training in Emotional intelligence represents a potentially attractive route to designing and evaluating interventions that do not require access to these aspects and instead managers may be taught to better handle the emotions triggered by their environment.

\section{REFERENCES}

[1] Carman,A. (2001). "Staff burnout and patient satisfaction." Journal of occupational health psychology,7,235-241.

[2] Caruso, D. R., \& Salovey, P. 2004. The emotionally intelligent manager. San Francisco: Jossey-Bass.

[3] Ciarrochi, J., Chan, A.Y.C., \& Bajgar, J. (2001). Measuring emotional intelligence in adolescents. Personality and Individual Differences, 31, 1105-1119.

[4] Ciarrochi, J., Deane, F.P., \& Anderson, S. (2002). Emotional intelligence moderates the relationship between stress and mental health. Personality and Individual Differences, 32, 197-209.

[5] Cordes, C. L., \& Dougherty, T. W. (1993). A review and an integration of research on job burnout. Academy of Management Review, 18: 621656.

[6] Day, A.L., Therrien, D.L., \& Carroll, S.A. (2005). Predicting Psychological Health: Assessing the incremental validity of emotional intelligence beyond personality, type A behaviour, and daily hassles. European Journal of Psychology, 19, 519-536.

[7] Elfenbein, H. A. (2006). Learning in emotion judgments: Training and the cross-cultural understanding of facial expressions. Journal of Nonverbal Behavior, 30: 21-36.

[8] Freudenberger,H.J.(1974). "Staff burnout." Journal of social issues, 30, 150-165

[9] George, J. M. (2000). Emotions and leadership: The role of emotional intelligence. Human Relations, 53: 1027-1055.

[10] Goleman, D. (1998). Working with Emotional Intelligence. Bantam Books, New York.

[11] Goleman, D. (1995). Emotional Intelligence: What it can Matter More than IQ. Bloomsbury Publishing, London, pp: 368, ISBN: 0747528306.

[12] Jordan, P. J., Ashton-James, C. E., \& Ashkanasy, N. M. (2006). Evaluating the claims: Emotional intelligence in the workplace. In K. R. Murphy (Ed.), A critique of emotional intelligence: 189-210. Mahwah, NJ: Lawrence Erlbaum.

[13] Lee, R. T., \& Ashforth, B. E. (1993). A longitudinal study of burnout among supervisors and managers: Comparisons between the Leiter and Maslach 1988 and Golembiewski et al. 1986 models. Organizational Behavior and Human Decision Processes, 54: 369-398.

[14] Lee, R. T., \& Ashforth, B. E. (1996). A meta-analytic examination of the correlated of the three dimensions of job burnout. Journal of Applied Psychology, 81: 123-133.

[15] Maslach, C., Schaufeli, W. B., \& Leiter, M. P. (2001). Job burnout. Annual Review of Psychology, 52, 397-422.

[16] Maslach, C., Jackson, S. E., \& Leiter, M. P. (1996). Maslach Burnout Inventory manual, 3rd ed. Mountain View, CA: CPP

[17] Maslach,C. and Jackson,S.E.(1993). Manual of the Maslach Burn out Inventory"( $2^{\text {nd }}$ ed). Palo Alto: Consulting psychologist press Inc

[18] Mayer, J. D., Salovey, P., \& Caruso, D. R. (2004). Emotional intelligence: Theory, findings, and implications. Psychological Inquiry, 15, 197-215.

[19] Mayer, J. D., Salovey, P., Caruso, D. R., \& Sitarenios, G. (2003). Measuring emotional intelligence with the MSCEIT V2.0, Emotion, 3 , 97-105.

[20] Mayer, J.D., R.D. Roberts and S.G. Barsade (2008). Human abilities: Emotional intelligence. Annu. Rev. Psychol., 59: 507-536.

[21] Murphy, K. R. (2006). A critique of emotional intelligence. Mahwah, NJ: Erlbaum.

[22] Petrides, K.V., \& Furnham, A. (2000). On the dimensional structure of emotional intelligence. Personality and Individual Differences, 29, 313320.

[23] Pines, A., \& Aronson, E. (1988). Career burnout: Causes and cures. The Free Press: New York. 
[24] Saklofske, D.H., Austin, E.J., \& Minski, P.S. (2003). Factor structure and validity of a trait emotional intelligence measure. Personality and Individual Differences, 34, 1091-1100.

[25] Salovey, P., \& Mayer, J. D. (1990). Emotional intelligence. Imagination, Cognition and Personality, 9, 185-211.

[26] Schmit, M. J. (2006). EI in the business world. In K. R. Murphy (Ed.), A critique of emotional intelligence: 211-234. Mahwah, NJ: Erlbaum.

[27] Schutte, N.S., Malouff, J.M., \& Bhullar, N. (2009). The Assessing Emotions Scale. C. Stough, D. Saklofske \& J. Parker (Eds.), The Assessment of Emotional Intelligence. New York: Springer Publishing, 119-135.

[28] Schutte, N.S., Malouff, J.M., Hall, L.E., Haggerty, D.J., Cooper, J.T., Golden, C.J., \& Dornheim, L. (1998). Development and validation of a measure of emotional intelligence. Personality and Individual Differences, 25, 167-177

[29] Slaski, M., \& Cartwright, S. (2002). Health, performance, and emotional intelligence: An exploratory study of retail managers. Stress and Health, 18 (2), 63-68.

[30] Totterdell, P., \& Parkinson, B. 1999. Use and effectiveness of selfregulation strategies for improving mood in a group of trainee teachers. Journal of Occupational Health Psychology, 4: 219-232.

[31] Wong, C. S. \& Law, K. S. (2002). The effects of leader and follower emotional intelligence on performance and attitude: An exploratory study. Leadership Quarterly, 13: 243-274. 